\title{
DEVELOPING READING MATERIAL BASED-ON LOCAL CULTURE FOR JUNIOR HIGH SCHOOL IN KABUPATEN REJANG LEBONG
}

\author{
Leni Agustina ${ }^{1}$, Alamsyah Harahap ${ }^{2}$, Syahrial $^{3}$ \\ Postgraduate English Program Faculty of Teacher Training and Education, \\ University of Bengkulu \\ Email: azra870@gmail.com. ${ }^{1}$, \\ alamsyahharahap18@yahoo.com. ${ }^{2}$.Eric.Syahrial@gmail.com ${ }^{3}$
}

\begin{abstract}
Nowadays, the developing and appreciating material based on student's local culture is very attractive. The objectives of this research are to know the existing folktales in students' book, to identify local folktales that suitable to be included in the English students' book and to know how to include the local folktales in the English students' book for ninth grade of Junior High School in Rejang Lebong. This research adapted the R\&D model proposed by Borg and Gall (1983) with some modifications. The data was taken from students and teachers of SMP Negeri 1 Rejang Lebong, SMP Negeri 2 Rejang Lebong and SMP Negeri 5 Rejang Lebong through questionnaire and interview. The first result of this research shows that students like the existing folktales in students' book but sometimes they found difficulties in comprehending it. The second result identifies three siutable local folktales suitable to be included in the students' book; Legenda Batu Menangis (62.4\%), Lalan Belek (66.7\%) and Muning Raib (66.7\%). The third result shows that the developed material can be used as supplementary reading material. In conclusion, the existing folktales in the student's book are good but not contextual, there are highly three suitable local folktales to be included in students' book (Legenda Batu Menangis, Lalan Belek, and Muning Raib) and the way to include the suitable local folktales in English students' book is as supplementary reading material. As suggestion, the next researcher can conduct further study on evaluation by using try out of this material development.
\end{abstract}

Keyword: Developing reading material, local culture, supplementary material.

\begin{abstract}
ABSTRAK
Pengembangan dan pembaharuan bahan ajar berdasarkan kearifan lokal sangat menarik saat ini. Penelitian ini bertujuan untuk mengetahui sejauh mana cerita rakyat yang ada pada buku siswa, mengidentifikasi dan menambahkan cerita lokal ke dalam buku siswa dan untuk memasukkan cerita rakyat lokal ke dalam buku siswa SMP kelas sembilan di kabupaten Rejang Lebong sebagai tambahan bahan ajar. Penelitian ini menggunakan model penelitian dan pengembangan Borg dan Gall (1983) dengan beberapa modifikasi. Data penelitian ini diambil dari siswa dan guru SMP Negeri 1 Rejang Lebong, SMP Negeri 2 Rejang Lebong dan SMP Negeri 5 Rejang Lebong melalui kuesioner dan wawancara. Hasil dari penelitian ini menunjukkan bahwa siswa menyukai cerita rakyat yang ada di dalam buku teks tetapi kadang-kadang mereka mengalami kesulitan untuk memahaminya. Penelitian ini juga mengidentifikasi 3 (tiga) cerita rakyat Rejang Lebong yang sesuai dimasukkan ke dalam buku siswa yaitu; Legenda Batu Menangis (62,4\%), Lalan Belek (66,7\%) dan Muning Raib (66,7\%). Materi yang telah dikembangkan ini dapat digunakan sebagai bahan belajar membaca tambahan. Kesimpulan dari penelitian ini adalah cerita rakyat yang ada di dalam buku teks menarik tetapi tidak kontekstual bagi siswa di Kabupaten Rejang Lebong, terdapat tiga cerita rakyat yang dapat dimasukkan kedalam buku siswa sebagai bahan belajar membaca tambahan. Saran penelitian ini ditujukan pada peneliti berikutnya untuk melaksanakan evaluasi yang menekankan pada uji coba materi yang telah dikembangkan.
\end{abstract}

Kata Kunci: Pegembangan bahan ajar membaca, budaya lokal, bahan ajar tambahan. 


\section{INTRODUCTION}

Culture is one of the important elements in learning a language. Language and culture cannot be separated. Students have to acquire the language and the culture (Byram, 1990; Byram \& Flemming, 1998). When students learn a language, automatically they will learn the culture of the language. It is part of communicative competence which includes cultural understanding, conversation, society norms and values. Acquiring the language and the culture at the same time is rather difficult for the students, especially for beginner like Junior High School students. Teacher should find a text which is useful, interesting, engaging, involving, important, and relevant to their lives. Teacher should provide the text that is familiar for the students. If the students have already known the content of the text, teacher can help them to draw their attention to the language (Masuhara, 2003).

Obviously, the students and the teacher come from the same cultural background and the same language. It enables them to communicate and develop idea about local culture that they are familiar with. It is supported by Vygotsky's sociocultural theory (1994) on second language acquisition said that in acquiring a language is influenced not only by cognitive side but also by the environment of social and cultural around the students. Interaction between the students and teacher in a real sociocultural setting will encourage them to participate in the classroom.

Responding to this view, the teaching-learning materials and activities should also cover the local culture of students to meet the students' background knowledge, emotion, experience, and culture (Bao, 2016; Tomlinson, 2012;
Mckay, 2003). If the students are given unfamiliar topic to be discussed, they are most likely to give up and take time to do so. If the topic is familiar for them, they will be easy to comprehend the materials and the learning will take place. They have background knowledge about the topic and know what they are going to discuss. They will engage actively with the lesson.

Furthermore, the government of Indonesia on the National Education system suggests that the teachers' responsibility for maintaining the Indonesian culture relate to the values of religion and local wisdoms. Teachers have an important role in integrating cultures or cultural elements in teaching and learning process. As textbooks are generally considered to be the major source of the teaching materials in the classroom, they have an important role in integrating cultures or cultural elements in the teaching and learning process. There are many textbooks published and used but they contain many culture values because they are produced for national level of the country.

Based on the researcher's observation in the textbook used by ninth grade students of SMP Negeri 5 Rejang Lebong entitle Think Globally Act Locally, the existing materials contain the cultures of Java, Bali, Palembang, and other Indonesian cultures. It differs from the students' culture. They should comprehend a text from other culture in their nation, for example they have to comprehend the text from Java like Mount Bromo, Tangkubanperahu, Banyuwangi, and Borobudur Temple. Although the texts are famous for Indonesian people, the students are still difficult to comprehend the text because they do not have background knowledge of the text. It will make the learning process does not take place. Mukundan (2003) proposes 
that it is more valuable to develop reading material that suit with students' background knowledge, experience, interest, emotion and culture.

Culture-based learning can be classified as a representation of contextual-learning approach. Contextually, the learning process should be relevant to the real situation and the culture where the learners are (Bao, 2016; Tomlinson, 2012; Mckay, 2003). The culture-based covers all principles, norms, and practical orientation which happen among the society. This evidence then is used as the orientation in developing the reading material; culture-based reading material is referred to the use of material taken from Rejang Lebong culture. In line with this case, the learning process will be more beneficial and interesting for the learners since it directly applies their daily lives.

Based on con structivism theory developed by Piaget (Marysia, 2003), everybody has his own definition toward his learning and he will relate it to his prior knowledge. A learner will achieve such knowledge through the process of adding, modifying, and revising all the information during his learning. Constructivism theory also strengthens that every individual exactly bring along his prior knowledge during the learning. Brooks \& Brooks (1993) stated that the culture-based learning which goes along with the constructivism theory will create such a very convenient learning process. Kusuma (2012) found that by applying culture based in the classroom, the teacher has played the role as a professional educator; helping the learners to do some of the following things:

1. Seeing the relevance between principle of the subject matter and the different culture context.

2. Understanding all the subject matter and the culture where the learners live.
3. Actively participating in the culturebased learning process.

4. Having the learners ${ }^{\text {ee }}$ knowledge and experience by varying the classroom activities.

5. Understanding the nature of culture as such community where the learners are being learned and as it is seen from the educational point of view.

6. Having an understanding and being competent to perceive all things around the learner's daily life.

There are studies on developing reading materials based on local culture such as Kusuma (2012); Utami (2014); and Arifani (2016). Kusuma and Utami had concerned on developing reading materials focus on topics about: traditional clothes, traditional food and drink, tourism object, famous public figure, traditional music and dance of Balinese. Arifani developed fifteen chapters containing local reading passages from various famous local tourism objects, famous public figures, cultures, traditional cuisine and music. However, there are no studies that focus on topic of local folktale of the culture. Considering this fact, this study will develop local culture reading material focus on folktale or narrative text for the ninth grade students of Junior High School students in Rejang Lebong. The primary questions adressed in this research are as follow:

1. How are the existing folktales in the English students's book for ninth grade of Junior High Schools in Rejang Lebong?

2. What local folktales are suitable to be included in the English students' book for ninth grade of Junior High Schools in Rejang Lebong?

3. How to include the local folktales developed in the English students' book for ninth grade of Junior High Schools in Rejang Lebong? 


\section{METHODOLOGY}

This was Research and Development (R \& D) study which aimed to develop effective product based on the result of need analysis. It was conducted to design reading materials based on local culture for the students of ninth grade of Junior High Schools in Kabupaten Rejang Lebong. Borg and Gall (2003) state that R $\& D$ is a process to develop and validate the educational product by testing it. They suggest that the product should be systematically field-tested, evaluated, and refined until they meet specified criteria of effectiveness, quality, or similar standards.

The respondents of the research were the ninth grade students of SMPN 1 Rejang Lebong, SMPN 2 Rejang Lebong and SMPN 5 Rejang Lebong and their teachers. The total numbers of the ninth grade students were 93 persons (31 students from SMPN 1 RL, 33 students from SMPN 2 RL, 29 students from SMPN 5 RL). There were 9 teachers who taught ninth grade (3 English teachers from SMPN 1 RL, 3 English teachers from SMPN 2 RL, 3 English teachers from SMPN 5 RL).

The instruments of this research were questionnaire and interview. There were two kind of questionnaires used. The first questionnaire is for the students and the teachers to identify the needs of local culture reading materials for ninth grade of Junior High School in Rejang Lebong. The second questionnaire is for expert judgement to evaluate the material developed.
This study simplified Borg and Gall's model into five steps, because this study only developed the models of reading material based on local culture. They were conducting need analysis, writing the syllabus, developing the material, evaluating and revising.

The data would be analysed quantitatively and qualitatively. The questionnaire consisted of several questions which asked the students and teachers to choose the answer and gave the reason of their answers based on their experience in teaching and learning reading. After they had filled the questionnaire, the score would be counted. Then, the data from the questionnaire would be analysed quantitatively by using percentage (Arikunto, 2010). It described the percentage of each statement/question from the students and the teachers to identify the needs of local culture reading materials for ninth grade of Junior High School in Rejang Lebong. The formula of percentage:

$$
\mathrm{P}=\frac{\mathrm{F}}{\mathrm{N}} \mathrm{-------} \text { X 100\% }
$$

Where:

$\mathrm{P}=$ the percentage of students need

$\mathrm{F}=$ frequency

$\mathrm{N}=$ total number

After the data has been calculated, the criteria of the percentage are described as table 1 follow: 
Table 1 . The range/criteria of the percentage

\begin{tabular}{|c|c|}
\hline Percentage & Criteria \\
\hline $81 \%-100 \%$ & Excellent \\
\hline $61 \%-80 \%$ & Very good \\
\hline $41 \%-60 \%$ & Good \\
\hline $21 \%-40 \%$ & Fair \\
\hline $0 \%-20 \%$ & Poor \\
\hline
\end{tabular}

(Adopted from Arikunto: 2007)

The percentage of all the data was acquired based on those criteria. The student's preference was accumulated from all the students' answers of each statement divided with the total number of students. While the teachers preference was accumulated from all the teachers' answers of each statement divided with the total number of the teachers. The researcher focused on the criteria "Very good and Excellent". The Statistical service centre (2001:23) states that $60 \%$ is the popularity summaries that readers find them accessible, convenient and to a degree useful.

After gathering the information from the interview, the researcher analysed the data by writing the conversation transcript, describing the data, and writing the conclusion. Firstly, the researcher rewrote each interview conversation conducted to the respondents by repeating the record and reading important notes written by researcher during the interview. After that the researcher classified the answers into the categories information needed as the answer to the problems asked in this research. Then, the researcher drew the conclusions of all data gathered to develop model of local culture reading material.

The data obtained by using expert judgment questionnaire were analysed by using Likert-scale as measurement. There were four options in the first questionnaire: Strongly Agree (SA), Agree (A), Disagree (D) and strongly Disagree (SD). The score of each scale are presented below:

.Table 2. The score of each option

\begin{tabular}{|c|c|c|}
\hline No & Categories & Score \\
\hline 1 & Strongly Agree (SA) & 4 \\
\hline 2 & Agree (A) & 3 \\
\hline 3 & Disagree (D) & 2 \\
\hline 4 & Strongly Disagree (SD) & 1 \\
\hline
\end{tabular}

From the data collection above, the Mean (x) from the data can be calculated using formula proposed by Suharto (2005).

$$
\text { Mean }=\frac{\sum f x}{N}
$$

The mean values can be put on categories in order to make the data easier to read. The formula was proposed by Suharto and can be seen as follows:

$$
\mathrm{R}=\frac{(\mathrm{Xh}-\mathrm{Xl})}{4}
$$

Where:

$\mathrm{R}$ : Range

$\mathrm{Xh}$ : The highest scale

$\mathrm{Xl}$ : The lowest scale 
The result of the calculation was converted into descriptive analysis. Data conversation table was used to convert the data as the mean of the data had been calculated.

Table 3. Data Conversion Table

\begin{tabular}{|c|c|c|}
\hline Scale & Interval & Descriptive Categories \\
\hline 1 & $1 \leq \mathrm{x} \leq 1.74$ & Poor \\
\hline 2 & $1.74 \leq \mathrm{x} \leq 2.24$ & Fair \\
\hline 3 & $2.5 \leq \mathrm{x} \leq 3.24$ & Good \\
\hline 4 & $3.24 \leq \mathrm{x} \leq 4$ & Very Good \\
\hline
\end{tabular}

The second data from open-ended questions in the second questionnaire were analysed through four steps: collecting data, reducing data, data displaying, and drawing the conclusions. In the data reduction step, the data are selected, limited, simplified, and transformed by summarizing the answers of open-ended questions.

Table 4. The Existing Reading Material

\begin{tabular}{|c|c|c|c|}
\hline Questions & Items & Student & Teacher \\
\hline $\begin{array}{l}\text { Is the existing folktale } \\
\text { interesting? }\end{array}$ & $\begin{array}{l}\text { a. Interesting } \\
\text { b. Interesting enough } \\
\text { c. Very interesting } \\
\text { d. Not interesting }\end{array}$ & $\begin{array}{l}17.3 \% \\
62,4 \% \\
7.5 \% \\
12.9 \%\end{array}$ & $\begin{array}{l}22.2 \% \\
77.8 \% \\
0 \\
0\end{array}$ \\
\hline Is the existing folktale easy? & $\begin{array}{l}\text { a. Easy } \\
\text { b. Difficult enough } \\
\text { c. Difficult } \\
\text { d. Very difficult }\end{array}$ & $\begin{array}{l}28.0 \% \\
61.3 \% \\
8.6 \% \\
32.2 \%\end{array}$ & $\begin{array}{l}55.5 \% \\
44.4 \% \\
0 \\
0\end{array}$ \\
\hline $\begin{array}{l}\text { Is the existing folktale } \\
\text { useful? }\end{array}$ & $\begin{array}{l}\text { a. Useful enough } \\
\text { b. Useful } \\
\text { c. Very useful } \\
\text { d. Not useful }\end{array}$ & $\begin{array}{l}26.9 \% \\
51.6 \% \\
18.3 \% \\
3.2 \%\end{array}$ & $\begin{array}{l}22.2 \% \\
33.3 \% \\
44.4 \% \\
0\end{array}$ \\
\hline $\begin{array}{l}\text { If you have not known the } \\
\text { folktale, do you find } \\
\text { difficulties } \\
\text { comprehending it? }\end{array}$ & $\begin{array}{l}\text { a. Yes } \\
\text { b. No }\end{array}$ & $\begin{array}{l}69.9 \% \\
26.9 \%\end{array}$ & $\begin{array}{l}100 \% \\
0\end{array}$ \\
\hline
\end{tabular}

The existing folktales in the student's book for ninth grade of Junior 
High School (Sangkuriang, The Golden Cucumber, Telaga Warna and other Indonesian folktales) are good to be used in the teaching and learning process based on the students' and teachers' opinions. Most of the students and the teachers think that the folktales in the textbook used are quite interesting and not too difficult. Students love to read the folktales and encourage them to learn. It can help the teaching and learning process runs smoothly. The existing folktales help students to develop their confidence. However, sometimes the students find difficulties in comprehending the story because they do not know the story about. They do not have background knowledge about the story. It can be concluded that the existing folktales are good to be used in the teaching and learning process but they are not contextual for the ninth grade students of junior high school in Kabupaten Rejang Lebong. Here is the interview excerpt with one of the student $(\mathrm{Nd})$.

"Kadang-kadang, kadang menarik, kadang tidak. Tidak menarik karena saya tidak mengerti dengan isi teks tersebut." (23 Januari 2018, 09.06 WIB)

"Sometimes, it is not interesting if I do not understand the content of the text." (January 23rd 2018, 09.06 WIB)

The result of this research is similar with Kusuma (2012) and Utami (2014). Kusuma (2012) found that the existing materials were not contextual for the students of ninth grade of elementary schools in Buleleng Regency, Bali. Utami (2014) identified topic selection as one problem in reading for the eight grade students of SMP Laboratorium, Singaraja, Bali. In this research, most students and teachers think that the existing folktales do not always suit with the students' background. It is difficult for the students to acquire the language and the text at the same time. They believed that if the students have background knowledge about the text, they will be easy in comprehending it. Then, It is suggested to the teachers to suit the reading materials (folktales) with students' background knowledge (Bao, 2016; Tomlinson, 2012; Mckay, 2003).

It can be seen that there is still a width opportunity to increase students' reading comprehension through local folktales. It is hoped that by using local folktales that are familiar for the students, it will be easier for them to comprehend the text. They have already had background knowledge about the local folktales so teacher can help the students to draw their attention to the language (Masuhara: 2003). Students can focus to learn about the use of simple past tense, adverb of time in simple past tense and certain vocabularies in narrative text.

\section{The Need of Local-Folktales}

The learning needs are focused on what the learners will have to do with the reading material. It is found that there are different choices between the students and the teachers about local folktales that can help the students easy to comprehend the text. It is possibly because not all respondents of the research comes from Rejang Lebong. Some of them come from Padang, Batak, Jawa, Palembang, and other cities in Indonesia, only few of them are native of Rejang Lebong. Below table is the result of the learning needs questions in need analysis. 
Table 5. The Need of Local Folktale Reading Materials

\begin{tabular}{|c|c|c|c|}
\hline Questions & Items & Student & Teacher \\
\hline $\begin{array}{l}\text { Have you ever read Rejang } \\
\text { Lebong's folktale in English? }\end{array}$ & $\begin{array}{ll}\text { a. } & \text { Ever } \\
\text { b. } & \text { Never }\end{array}$ & $\begin{array}{l}22.6 \% \\
77.8\end{array}$ & $\begin{array}{l}22.2 \% \\
77.8 \%\end{array}$ \\
\hline $\begin{array}{l}\text { Which Rejang Lebong"s folktale } \\
\text { have you ever read? }\end{array}$ & $\begin{array}{l}\text { a. Lalan Belek } \\
\text { b. Muning Raib } \\
\text { c. The legend of crying } \\
\text { stone } \\
\text { d. Tri Sakti } \\
\text { e. Jagok Setahun } \\
\text { f. Others......... }\end{array}$ & $\begin{array}{l}23.7 \% \\
22.6 \% \\
62.4 \% \\
6.5 \% \\
1.1 \% \\
8.6 \%\end{array}$ & $\begin{array}{l}66.7 \% \\
66.7 \% \\
0 \\
0 \\
0 \\
11.1 \%\end{array}$ \\
\hline $\begin{array}{l}\text { Will the folktales above make } \\
\text { students easier to comprehend } \\
\text { them? }\end{array}$ & $\begin{array}{l}\text { a. Yes } \\
\text { b. No }\end{array}$ & $\begin{array}{l}68.8 \% \\
30.1 \%\end{array}$ & $100 \%$ \\
\hline
\end{tabular}

There are three local folktales suitable to be included in the students' book for ninth grade of Junior High school in Rejang Lebong. They are Crying stone, Lalan Belek and Muning Raib. It is based on the finding of this research that the students have been familiar with the local folktale of Crying Stones. It is because most of the students have read the story in Suban Air Panas and in the library. There is a relief of crying stone in Suban Air Panas, one of tourism object in Rejang Lebong and people can read the brief story of cying stone in Indonesian. They have already known the story so it will make them easier to comprehend the story in English.

Based on constructivism theory developed by Piaget (Marysia, 2003), everybody has his own definition toward his learning and he will relate it to his prior knowledge. A student will achieve such knowledge through the process of adding, modifying, and revising all the information during his learning. Constructivism theory also strengthens that every individual exactly bring along his prior knowledge during the learning. Brooks \& Brooks (1993) stated that the culture-based learning which goes along with the constructivism theory will create such a very convenient learning process.

Meanwhile, the teachers choose the story of Lalan Belek and Muning Raib. They think both stories teach good moral value for the students. Moral value is one of the structures of narrative text. A story has a value that guide people throughout our lives. Sharma (2017) states that moral value are important in life because people can differentiate between good and bad, help build good relationship, help in eradicating problems, and a key to self-motivation. Some of the important values can be: honesty, hard work, respect for others, kindness and forgiveness.

It is also in line with what the government have introduce in the current curriculum about the importance of character education in school. Teacher should insert character education in teaching and learning process to strengthen the students' character (Peraturan Presiden nomor 87 tahun 2017). This program applies to strengthen the moral value of religious, honesty, tolerance, discipline, hard work, creative, democracy, curiosity, nationalism, love the nation, 
appreciation, communicative, peace, love reading, love the environment, social care and responsibility. The government of Indonesia wants to develop golden generation in 2045 to face the globalization era.

Furthermore, this research also identifies the teaching and learning activities that mostly preferred by the respondents. There are different preferences between students and teachers about strategy, evaluation and vocabulary activities in reading comprehension. Since the aim of this research is to help the students and the teachers in teaching and learning process, this research will follow the students' and teachers' choices. It is suitable with Faravani and Zeraatpishe (2006) proposes that in learner-centred syllabus, content should be derived from the process of consultation and negotiation with the students. Therefore, there should be considered in developing or designing material including determining postcourse communication needs, consulting and negotiating with the students.It can be seen on table 3 about the result of the teaching and learning activities questions in need analysis.

Table 6. Teaching and Learning Activities

\begin{tabular}{|c|c|c|c|}
\hline Item & Questions & Student & Teacher \\
\hline $\begin{array}{l}\text { Which strategy do you } \\
\text { prefer to comprehend a } \\
\text { text? }\end{array}$ & $\begin{array}{l}\text { a. Silent reading } \\
\text { b. Reading aloud } \\
\text { c. Finding main idea } \\
\text { d. Listening to the text } \\
\text { e. Identifying the purpose of the text } \\
\text { f. Understanding certain word } \\
\text { g. Semantic Mapping }\end{array}$ & $\begin{array}{l}76.3 \% \\
17.2 \% \\
45.2 \% \\
43 \% \\
1.1 \% \\
59.1 \% \\
7.5 \% \\
\end{array}$ & $\begin{array}{l}44.4 \% \\
33.3 \% \\
44.4 \% \\
77.8 \% \\
0 \\
100 \% \\
0\end{array}$ \\
\hline $\begin{array}{l}\text { Which evaluation do you } \\
\text { prefer? }\end{array}$ & $\begin{array}{l}\text { a. Multiple choice } \\
\text { b. Matching } \\
\text { c. Filling in the blank } \\
\text { d. True/False } \\
\text { e. Answering question } \\
\text { f. Essay } \\
\text { g. Information transfer }\end{array}$ & $\begin{array}{l}73.1 \% \\
37.6 \% \\
35.5 \% \\
54.8 \% \\
34 \% \\
21.5 \% \\
5 \%\end{array}$ & $\begin{array}{l}33.3 \% \\
55.5 \% \\
22.2 \% \\
100 \% \\
100 \% \\
33.3 \% \\
33.3 \%\end{array}$ \\
\hline $\begin{array}{l}\text { Which vocabulary } \\
\text { activity do you prefer? }\end{array}$ & $\begin{array}{l}\text { a. Translation } \\
\text { b. Games } \\
\text { c. Synonym } \\
\text { d. Antonym }\end{array}$ & $\begin{array}{l}68.8 \% \\
37.6 \% \\
39.8 \% \\
45.2 \%\end{array}$ & $\begin{array}{l}100 \% \\
44.4 \% \\
44.4 \% \\
11.1 \%\end{array}$ \\
\hline $\begin{array}{l}\text { Which activity do you } \\
\text { prefer in doing exercise? }\end{array}$ & $\begin{array}{l}\text { a. Individual } \\
\text { b. Pairs } \\
\text { c. Group }\end{array}$ & $\begin{array}{l}38.7 \% \\
54.8 \% \\
69.9 \%\end{array}$ & $\begin{array}{l}77.8 \% \\
55.5 \% \\
100 \%\end{array}$ \\
\hline
\end{tabular}

The most preference strategy chose by the students is silent reading. It is in contrary to Brown (2001) that silent reading is not suitable for beginner like junior high school students. He states that the beginners are still struggling with the control of limited vocabulary and grammatical patterns. The students still need control from their teacher like pronunciation. They do not need to pronounce every word to themselves. It is better for the student to learn to be an 
efficient reader, find the information that is needed to comprehend the text.

The teachers prefer listening and understanding certain word strategy in comprehending a text. Masuhara (2003) states that listening to a text before reading it helps decrease linguistic demands and encourages learners to focus on meaning. The major difficulty for the students to read is that reading involves a complex process of decoding sounds, words and sentences, getting meaning from the text and relates it with their relevant knowledge in order to comprehend the text. By teachers' reading the text to the students can help the students to interpret the text.

The students like the evaluation activity in the form of multiple choices. They like multiple choice because there are some answers provided and they just need to choose the best answer. If they are not sure about the correct answer, they will only guess one of the provided answers. Multiple choices are the simplest kind of item to construct but extremely difficult to design correctly (Brown: 2003). It is difficult for the teacher to design multiple choice items by themselves. The teachers prefer stating true/false and answering questions to asses students comprehension to the text. Those evaluations are mostly found in the textbook to measure students' ability in reading comprehension.

The students and the teacher think that translation is the best way for vocabularies activity. Based on the result of the interview with the teachers in this research, translation is the best way to help the students to overcome unknown words. They ask the students to look for the difficult words on their dictionary. It is hoped they can remember and use the words on their next lesson. Brown (2001) suggests the way to overcome students' problem in vocabulary through guessing the meaning by the context. They can look at the grammatical relationship, the discourse, the cultural reference and meaning between lines.

The students also like to work in group than work individually or in pairs. They think their friends will help them if they get difficulties, discuss the answers and make them more confident in doing the task. Based on the researcher experienced on teaching, some students' attitudes about group work are often negative; they do not work within their group, they depend on their friends, and they make noise. They only follow the result of their group. In contrary, Brown (2001) says those teachers still need to recognize and capitalize upon each student's differences. Group work can be implicated as a step to individualizing instruction. In learning English, individual activity is still needed to know students proficiency of the language. After conducting needs analysis, the syllabus was developed. The syllabus covers the language areas and knowledge which the learners had to learn. It is the guideline in developing the materials. The syllabus consists of topic, core competence and basic competence, indicator, learning material, and learning activities. The researcher also analysed the curriculum that was used in the teaching and learning process. The materials must be developed based on the core competencies and the basic competencies so that the learning objectives could be achieved.

The syllabus developed the local folktales that had been chosen by the students and the teachers in need analysis stage: The legend of Crying Stone, Lalan Belek and Muning Raib. The materials are intended to help the students in learning English especially comprehending narrative text not to help 
the teachers in teaching narrative text. The syllabus presented the materials based on the learning that had occurred in previous lesson. It is called the Linear approaches to sequencing by Nation (2010: 82). Students learn about generic features of The crying Stone story and they apply what they have learn in Muning Raib story. It did not only refer to the result of need analysis in term of teaching and learning activities but also some experts' suggestions and previous researches about good strategies and activities in reading.

Based on the syllabus, the researcher began to develop the first draft materials. The materials were divided into some parts: introduction, lesson proper, reinforcement, and fun grammar. The introduction consisted of warm up activity which aimed to build the students' awareness about the materials they are going to learn. Lesson Proper consisted of observing, questioning, collecting, analysing, communicating, and creating part which were the main activity of the material in the unit. Fun grammar part was developed to build and strengthen the students' further knowledge about grammar. The last was Reinforcement consisted of reflection and summary. It gave the students' chance to review what they were learning from the whole unit.

After the first draft of the materials had been developed, the materials were evaluated by an expert. The data of the expert judgment were obtained through a Likert-scale questionnaire which had four points. The items of the questionnaire evaluate the appropriateness of the content, appropriateness of the language, appropriateness of the presentation, and appropriateness of the graphic of the developed materials.
The result from expert's questionnaire shows that the mean value of the appropriateness of the content is 4 which can be categorized as "Very Good". The mean value of the appropriateness of the language is 4 which can be categorized as "Very Good". The mean value of the appropriateness of the presentation is 4 which can be categorized as "Very Good". The mean value of the appropriateness of the graphic is 3.2 which can be categorized as "Good".

In the expert judgment, the expert gives some suggestions to the developed materials. The suggestions from the expert are about the grammatical errors and wrong choices of words in the materials. The revisions of the first draft materials were considered as the final draft of the materials.

\section{The Way to Include the Local Folktales Identified}

The materials that have been developed are included in the English Students' book for ninth grade of Junior High school in Rejang Lebong as supplementary reading materials. It is caused that the students have already had background knowledge about the story. It makes them easy to learn and comprehend it by themselves. They can draw their attention on the use of language in the story. They can determine the objectives, comprehend the story and process their own learning.

It is similar with Kristianasari and Suharmanto (2014) and Astuti and Mariana (2015) in their research found that teacher should find another sources of material because the existing reading materials in the textbook are not adequate. Teacher should adapt the reading materials in the textbook with supplementary reading materials which 
suit with the students and can be used independently. The supplementary reading material is to add the published materials in both quantitative and qualitative changes. Islam and Mares (2015) states that teacher can supplement the existing material by either extending (quantitative changes) or expanding (qualitative changes).

Since reading is the foundation of other skills in language learning, there should be more time allocation for the students to have exposure to read before they can use it in their real need in school. Ironically, in our curriculum English classes has only four sessions a week, each of which lasts in 40 minutes. These sessions should be used to cover four language skills; listening, speaking, reading and writing (Peraturan Menteri Pendiikan dan Kebudayaan nomor: 22 tahun 2016). To compensate for lack of time, efforts should be made to develop the students' habit of autonomous learning.

Little (1991) states that being autonomous enables students to determine their objectives, defines the content and processes their own learning, select their methods and techniques, and monitor and evaluate their progress and achievements. To reach such learning situation, however, teacher does not only need to change the students' mind set and learning habit but also to improve their learning facilities including reading materials. Teacher should prepare the material that can help students to add their knowledge abbot the lesson at home. It should encourage the students to study by themselves. By giving local folktales, it is hoped that the students will be motivated in doing so because they have already had background knowledge about the story. It is easy for them to comprehend the text. Finally, they can focus their attention to the use of language in the text.

\section{CONCLUSION AND SUGGESTION}

Based on the research findings, conclusions can be drawn as follows. First, the existing folktales in the textbook (Sangkuriang, The Golden Cucumber, Telaga Warna and other Indonesian folktales) used by the ninth grade students of Junior High School in Rejang Lebong are good to be used in the teaching and learning reading but not contextual. Second, the suitable local folktales to be included in English students' book for the ninth grade of Junior High School in Rejang Lebong are; Legenda Batu Menangis (62.4\%), Lalan Belek (66.7\%) and Muning Raib (66.7\%). Third, the way to include the suitable local folktales in English students' book for the ninth grade of Junior High School in Rejang Lebong is as supplementary material to add and enrich the existing material.

The product of this research is reading materials for the ninth grade students of junior high school in kabupaten Rejang Lebong. Based on the research findings, there are suggestions proposed by the researcher for the teachers in junior high school. First suggestion is about the topic of the materials. The topic should be related to the daily activity so that the students are not confused about what they are learning. Exploring the social life of the students is suggested to be done by an English teacher. The second suggestion is concerning with the students' activity. Although the materials are about reading activities, the activities must be interesting by conducting some games and audio/visual during the reading activities. 
There are two suggestions proposed by the researcher for other researcher and/or other materials developers. The first suggestion is about the importance of conducting needs analysis. Conducting needs analysis is important because it helps the materials developers or researchers identify what kind of materials that should be developed. The last suggestion is that since the materials are evaluated only by the expert, it will be better if the materials are also evaluated by conducting a try-out. It can give a better evaluation for the developed materials.

\section{REFERENCES}

Arifani, Yudhi. (2016). Optimizing EFL Learners' sensitizing Reading Skill: Development of Local Content-Based Textbook. English Language Teaching 9(5).

Arikunto, (2010). Prosedur Penelitian Suatu Pendekatan Praktik Ed Revisi. Jakarta: Rineka Cipta.

Bao, Dat. (2016). "Improvements in Today's ELT Materials Development". In Azarnaoosh, Maryam, et. all. (Eds.). Issues in Materials Development. Sense Publisher: Rotterdam.

Borg, W and Gall, M.D. (1983). Educational Research: An Introduction. Longman: New York.

Brown, H. D. (2001). Teaching by Principles: An Interactive Approach to Language Pedagogy. Longman: San Fransisco.

Brown, H. D. (2003). Language Assessment: Principles and Classroom Practices. Longman: San Fransisco.

Brooks, Jacqueline G., and Brooks, Martin G. (1993). In Search of Understanding: The Case for Constructivist Classrooms. Alexandria, VA: Association for
Supervision and Curriculum Development.

Byram, M. (1990). Cultural Studies in Foreign Language Education. Multilingual Matters.

Byram, M. \& Flemming, M. (Eds.) (1998). Language Learning from an Intercultural Perspective. Cambridge: Cambridge University Press.

Faravani, A. \& Zeraatpishe, M. (2006). "Selection and Gradation in Materials Development". In Azarnaoosh, Maryam, et. all. (Eds.). Issues in Materials Development. Sense Publisher: Rotterdam.

Islam, C. \& Mares, C. (2016). "Adapting Classroom Materials". In Azarnaoosh, Maryam, et. all. (Eds.). Issues in Materials Development. Sense Publisher: Rotterdam.

Johnson, Marysia. (2003). A Philosophy of Second Language Acquisition. Yale University Press: London.

Kristianasari, R. \& Suharmanto. (2014). Supplementary Reading Materials for International Standard Junior High Schools Grade seven. Journal Online Universitas Negeri Malang vol.2, No.2 (2012).

Kusuma, I. P. I. (2012). Developing Reading Material For Elementary Students in Tourism Area By Inserting Local Culture. JEELS, 3(1).

Little, D. (1991). Learner Autonomy 1: Definitions, Issues, and Problems. Trinity College: Dublin.

Masuhara, Hitomi. (2003). "Materials For Developing Reading Skills". In Tomlinson, B. (Ed.). Developing Materials For Language Teaching. Continuum: London. 
Mckay, S. L. (2003). Toward An Appropriate EIL Pedagogy: Reexamining ELT assumptions. International Journal of Applied Linguistic, 13(1). (http://people.upr.br/ clarissa/pdf s/EILpedagogy-Mckay).

Mukundan, Jayakarana. et. all. (2016). "Developing Reading Materials for ESL Learners". In Azarnaoosh, Maryam, et. all. (Eds.). Issues in Materials Development. Sense Publisher: Rotterdam.

Nation I. S. P. \& Macalister J. (2010). Language Curriculum Design. New York: Routledge.

Statistical Services Centre. (2001). Approaches to the analysis of Survey Data. The University of Reading: United Kingdom.

Sharma, Swati. (2017). What is the Importance of Moral Values in our Life?. (https: //www.quora.com.)

Tomlinson, B. (2012). Introduction: Principles And Procedures of Materials Development. (http://assets.cambridge.org.7628 54-excerpt. Pdf).

Utami, Ida Ayu M. I. et. all. (2014). Developing Culture-Based Supplementary Reading Material for the Eighth Grade Students of SMP Laboratorium Singaraja. $e$ journal Program Pasca Sarjana Universitas Pendidikan Ganesha volume 2 tahun 2014.

Vygotsky, L.S. (1994). Mind in Society: The Development of Higher Psychological Processes. Cambridge: Harvard University. (2016). Peraturan Menteri Pendidikan dan kebudayaan Nomor 22 Tahun 2016 tentang Kompetensi Inti dan Kompetensi Dasar Kurikulum 2013.
- (2017). Peraturan Presiden Nomor 87 Tahun 2017 tentang Penguatan Pendidikan Karakter. 